\title{
Analysis of Resource Management Among Male and Female Cassava Farmers in Fadama III (AF) in Anambra State, Nigeria
}

\author{
Anyikwa Chikezie Friday ${ }^{1}$, Ezeano Caleb Ikechukwu ${ }^{1}$, Anunobi Chizoba Pamela ${ }^{1}$, \\ Umeh Onyebuchi Jonathan ${ }^{1}$, Anyawu Onwukwe Sixtus ${ }^{2}$ \\ ${ }^{1}$ Department of Agricultural Economics and Extension, Nnamdi Azikiwe University, Awka, Nigeria \\ ${ }^{2}$ Department of Agricultural Science, Ignatius Ajuru University of Education, Port Harcourt, Nigeria
}

Email address:

Chikezieanyikwa1987@gmail.com (A. C. Friday)

To cite this article:

Anyikwa Chikezie Friday, Ezeano Caleb Ikechukwu, Anunobi Chizoba Pamela, Umeh Onyebuchi Jonathan, Anyawu Onwukwe Sixtus. Analysis of Resource Management Among Male and Female Cassava Farmers in Fadama III (AF) in Anambra State, Nigeria. International Journal of Agricultural Economics. Vol. 4, No. 6, 2019, pp. 259-266. doi: 10.11648/j.ijae.20190406.12

Received: September 17, 2019; Accepted: October 22, 2019; Published: October 29, 2019

\begin{abstract}
This study was conducted to analyze the resource management among male and female cassava farmers in FADAMA III (AF) in Anambra State, Nigeria. A multi-stage sampling method was used to select a total of 144 (72 men and 72 women) respondents for the study. Structured questionnaire was the primary instrument used for data collection. Data collected were analyzed using descriptive statistics, multiple regression analysis, allocative efficiency model, principal factor analysis, and independent sample t-test at 0.05 level of significant. The study revealed that the mean age of farmers were 43 year for male and 39 years for female. This suggested that farmers are in their active farm age in the study area. Also, the mean farming experience was found to be 17 years for male and 8 years for female. Thus, this is an indication that male cassava farmers were better experienced than their female counter part. Equally, the mean farm size was $2.2 \mathrm{ha}$ for male and $1.8 \mathrm{ha}$ for female. The significant explanatory variables for the production function for male were stem cutting, fertilizer, capital input, and labour. While that of female were stem cutting and labour only. Both the male and female farmers were inefficient in resource allocation and management.
\end{abstract}

Keywords: Cassava Production, Resource Use, Allocative Efficiency, Production Function

\section{Introduction}

Nigeria has an estimated population of over one hundred and eighty-three million people (183), constituting 92,387,474 males and 90,989,254 females [9]. Both male and female are responsible for producing the nation's food and one of the major problems confronting mankind in recent times is food crisis and Nigeria is not exempted [10]. Men and women are affected differently in their operation in factors like markets and socio-economics environments.

Agriculture is the largest sector in the Nigeria economy, providing food, income and employment for sustainable livelihood of both the rural and urban population [16]. Root crops constitute the largest component of food crop subsector of Nigeria's agriculture [4]. Root and tubers are major sources of dietary carbohydrates and provide food for over
60 million people in Nigeria [21]. Increase in the output of cassava, yam, potatoes and cocoyam will significantly increase the gross domestic product (GDP) of Nigeria [1]. The contribution of the root crop sector to the Nigeria agriculture is significant with cassava taking the lead among the other root crops in terms of high GDP [1].

Cassava originates from tropical America, introduce in Africa by the Portuguese in the Congo basin around 1558. It was initially produced for human consumption and recently cultivated for the production of dry chips (used as animal feed), ethanol and starch. Nigeria is the world largest producer of cassava with other top producers being Indonesia, Thailand, the Democratic Republic of Congo and Angola [5, 7]. It was estimated that in 2020, Nigeria's production of cassava would reached 60million tones and that the country has consistently been ranked as the world's 
largest producer of cassava since 2005 [5].

Comparing the output of various crops in Nigeria, cassava production ranks first, followed by rice and yam production [21]. This large harvest in Nigeria is attributed to internal market demand, availability of high yielding improved varieties of cassava stem, and increase hectare of farm land allocated to cassava in the country. Broadly speaking, cassava growing belts falls within three agro-ecological zones in Nigeria which includes: southwest, southeast, and the northcentral regions. As a staple food, cassava has certain inherent characteristics which make it attractive to all categories of farmers in the country. The crop have the ability of thriving on harsh soils where other crops, most especially grains, failed, it can also withstand drought and flood and is relatively cheap to cultivate as it requires low amount of inputs, which also makes it attractive to peasant farmers. $[15,5,1]$. However, Cassava is widely acknowledged and the scope of agricultural production can be expanded and sustained by peasant farmers within the limits of existing resource base and available technology if farm productivity is raised by efficient use of resources [8].

This elucidation therefore, forms the fundamental point why the concept of farm management has remained important economic study especially in developing agricultural economies like Nigeria, where resources are meager and opportunities for developing and adopting better technologies are dwindling. Efficiency analysis in agricultural production is generally associated with the possibility of farms producing a certain level of output from a given bundle of resources or certain level of output at least cost [2, 8]. Also technical efficiency implies the ability of a firm to obtain maximum output from the given inputs. It is the ratio of output to input and the greater the ratio, the more the magnitude of technical efficiency [21, 17, 8] and [19]. According to [21, 8] and [19], a production process may be technically inefficient if it fails to produce maximum output from a given bundle of inputs and is therefore operating beneath its stochastic production frontier. However, the analysis of allocative efficiency usually assumes that the farm firm seeks to optimize a profit maximization objective function subject to resource constraint. Resources are said to be efficiently allocated when the value of marginal product of each resource equals its price [21, 8, 16, 19]. Allocative efficiency of resource use is critical to enhanced productivity and incomes [2, 8, 18]. The major goal of any production system is the attainment of an optimally high level of output with a given amount of input. In the attainment of optimal level of output, resource productivity is paramount. Thus, efficient utilization of resources is also fundamental to achieving a broad-based economic and agricultural growth. Allocation efficiency is the kind which takes unit prices of inputs into consideration. It is the choice of input level which is consistent with relative factor price. In other words, a firm is said to be efficient in allocation of resources if it is capable of equating the marginal value product (MVP) of the input to its unit price hence, it is also referred to as pricing efficiency [18]. This means that the farm has the ability to maximize profit with respect to that input factor.

Government research effort under cassava development programme had led to the development of several programs aimed at adding value to cassava production, for example the National Root Crops Research Institute (NRCRI, 1999) and National Fadama Development Project I (NFDP), NFDPII, NFDP III and NFDP III (AF) from 1993 till date. The name "Fadama" is an Hausa name for irrigable land usually lowlying plains underlay by shallow aquifers found along Nigeria's major river systems. The NFDP I, II and III were adjudged successful by both national and international assessors culminating in the Federal Government of Nigeria requesting the World Bank for an Additional Financing aimed at sustainably increasing income of beneficiary groups such as Fadama Users Groups (FUGs) and Fadama Community Association (FCAs) in all the participating states [20]. Also, dissemination of these programs as well as advocacy supports for overall development of cassava are effective strategies for optimizing utilization of the abundant potentials associated with cassava in Nigeria.

Given the importance of cassava and the fact that its cultivation is increasing but the gap between the demand and supply is worrisome owing to the fact that there is a rapid growth in population and an increase in the use of land for non-agricultural purposes, it becomes compelling to examine the production methods, practices and resource inputs for its production in other to identify opportunities for improvements in terms of cultivation and efficient use of available resources. Thus, the study seeks to specifically:

i. determine the socio-economic characteristics of male and female cassava farmers,

ii. estimate the male and female cassava farmers production function,

iii. calculate the farmer's allocative efficiency, and

iv. identify the problems facing male and female cassava farmers in the study area.

Null Hypothesis (Ho)

There is no significant difference in the cassava output among male and female Fadama III (AF) participants.

\section{Research Methodology}

Study area: The study was carried out in Anambra state of Nigeria. The state is made up of 21 Local Government Areas. Anambra state is in Southeastern Nigeria. Boundaries are formed by Delta State to west, Imo state and Rivers State to South, Enugu state to the east and Kogi to the North. The National Population Commission in 2006 estimated the population to be $4,055,038$ with density of $846 / \mathrm{km}^{2}$ $(2,200 / \mathrm{sqm})$ and Total Land Mass of $4,854 \mathrm{~km}^{2}$. It is located between latitude $6^{\circ} 45^{\circ}$ and $5^{\circ} 44^{\circ} \mathrm{N}$ and longitude $6^{\circ} 36^{\circ}$ and $7^{\circ} 29^{\circ} \mathrm{E}$ of the area within the Greenwich meridian.

\section{Population of the Study}

The population of the study consists of 1,017 female and 1,168 male cassava farmers in the four benefiting local Government, making it a total of 2,185 farmers.

Sampling techniques and sample Size

The research employed a multistage sampling technique and the eight (8) participating local government was grouped 
into the four (4) agricultural zones in Anambra state.

In the first stage, one local government area was purposively selected from each agricultural zone (Anambra East, Awka North, Ihiala and Orumba North) based on intensity of cassava production.

In the second stage, two communities were randomly selected from each local government and one (1) Fadama User Group (FUG) was randomly selected from each community making a total of eight (8) FUGs.

In the third stage eighteen (18) respondents were randomly selected from the eight Fadama users groups in the study area.

Furthermore, for equal opportunity nine (9) male and nine (9) female cassava farmers were randomly selected making a total of 144 ( 72 males and 72 females) respondents which formed the sample size.

\section{Method of Data Analysis}

The study utilized a combination of analytical tools of descriptive statistics, multiple regression analysis and inferential statistical tools. Objective 1 was achieved using descriptive statistics. Objective 2 was achieved using the multiple regression Model. Objective 3 was achieved using allocative efficiency model, and Objective 4 was achieved using principal factor analysis (PFA). The independent sample t-test was used to ascertain the significance of null hypothesis one. Thus, the model is stated as follows:

1) The descriptive statistics for objective 1 was mathematically stated;

$$
\bar{X}=\sum \mathrm{fx} / \mathrm{n}
$$

2) The multiple regression models was implicitly stated as:

$$
\mathrm{Y}=\mathrm{f}(\mathrm{X} 1, \mathrm{X} 2, \mathrm{X} 3, \mathrm{X} 4, \mathrm{X} 5, \mathrm{e})
$$

3) Allocative efficiency model was stated as:

$$
\mathrm{AE}=\frac{M V P}{M F C}
$$

4) Factor Analysis technique for objective 4 was stated thus;

$$
\mathrm{Xij}-\mathrm{i} 1 \mathrm{Fi} 1+\mathrm{i} 2 \mathrm{Fi} 2+\ldots \mathrm{jmFik}+\mathrm{eij}
$$

\section{Results and Discussions}

\subsection{Socioeconomic Characteristics of Cassava Farmers}

Findings on the socio-economic profile of cassava farmers in table 1 revealed that the mean age of farmers were 43 years for male and 39 years for female; this is an indication that the farmers are still in their active age in cassava production enterprise. At this age; the farmers are still willing to try new things in terms of adoption of innovative technology in agricultural sector. Majority (70.8\% and 69.8\%) of the male and female cassava farmers were married respectively with a mean farming experience of 17 years for male and 8 years for female. Furthermore, the study showed

\begin{tabular}{|c|c|c|c|c|c|c|}
\hline \multirow{2}{*}{ Variables } & \multicolumn{3}{|c|}{ Male $(n=72)$} & \multicolumn{3}{|c|}{ Female $(n=72)$} \\
\hline & Freq. & Percent (\%) & Mean & Freq. & Percent (\%) & Mean \\
\hline \multicolumn{7}{|l|}{ Age (Years) } \\
\hline Less than 21 & 0 & 0 & 43 & 0 & 0 & \multirow{5}{*}{39} \\
\hline $21-30$ & 3 & 5.2 & & 8 & 12.5 & \\
\hline $31-40$ & 22 & 32.3 & & 30 & 39.6 & \\
\hline $41-50$ & 36 & 45.8 & & 30 & 39.6 & \\
\hline $51-60$ & 11 & 16.7 & & 4 & 8.3 & \\
\hline \multicolumn{7}{|l|}{ Marital Status } \\
\hline Married & 53 & 70.8 & & 50 & 69.8 & \\
\hline Single & 12 & 17.7 & & 11 & 18.8 & \\
\hline Widow & 5 & 5.2 & & 6 & 6.3 & \\
\hline Widower & 6 & 6.3 & & 2 & 2.1 & \\
\hline Divorced & 0 & 0 & & 3 & 3.1 & \\
\hline \multicolumn{7}{|c|}{ Years of Experience } \\
\hline $1-10$ & 12 & 22.9 & 17 & 34 & 45.8 & \multirow{5}{*}{8} \\
\hline $11-20$ & 44 & 54.2 & & 31 & 42.7 & \\
\hline $21-30$ & 4 & 4.2 & & 5 & 9.4 & \\
\hline $31-40$ & 10 & 16.7 & & 1 & 1 & \\
\hline $41-50$ & 2 & 2.1 & & 1 & 1 & \\
\hline \multicolumn{7}{|c|}{ Farm size (Hectare) } \\
\hline Less than 0.5 & 2 & 2.5 & 2.2 & 1 & 1.0 & \multirow{4}{*}{1.8} \\
\hline $0.6-1.0$ & 34 & 46.3 & & 40 & 52.1 & \\
\hline $1.1-2.5$ & 24 & 35 & & 23 & 34.4 & \\
\hline Above 2.5 & 12 & 16.3 & & 8 & 12.5 & \\
\hline
\end{tabular}
that the mean farm size for male was $2.2 \mathrm{ha}$ and 1.8 ha for female.

Table 1. Distribution of socio-economic characteristics of Respondents.

Source: Field Survey Data, (2017). 


\subsection{Determination of Male Cassava Farmer's Production Function}

The Double $\log$ function with the highest $\mathrm{R}^{2}$ and in conformity with the a priori expectation was chosen as the lead equation or line of best fit.

Thus, the equations for the male farmer's production functions were stated as:

For male:

$$
\mathrm{LnY}=4.1293+0.07288 \operatorname{LnX}_{1}+0.1773 \operatorname{LnX}_{2}+0.0545 \operatorname{LnX}_{3}+0.6907 \operatorname{LnX}_{4}+0.0047 \operatorname{LnX}_{5}+0.0076
$$

The coefficients of Multiple Determinant $\left(\mathrm{R}^{2}\right)$ was 0.9924 which implies that $99.24 \%$ variation in yield were explained by the joint action of the independent variables, while the remaining $0.76 \%$ was as a result of error beyond the control of the male cassava farmers. The F-statistics value of $1725.4 * *$ significant at $1 \%$ level of probability is an indication that the model was normally distributed.

The coefficients of cassava cuttings $\left(\mathrm{X}_{1}\right)$ was positive and significant at $5 \%$ levels of probability, which implies that increase in Cassava cuttings will increase cassava output in the study area. A unit increase in cassava cutting would increase the output of cassava by $0.07288 \mathrm{~kg}$ of the male cassava farmers. This finding agrees with that of [12] and [2].

The coefficient of Fertilizer $\left(\mathrm{X}_{2}\right)$ was positive and significant at $1 \%$ level of probability, which implies that increase in the quantity of fertilizer used by male cassava farmers (when applied properly and at the appropriate time) will increase cassava yield in the area. A unit increase in fertilizer will increase the output of the male cassava farmers by $0.1773 \mathrm{~kg}$. This result disagrees with that of [14].

The coefficient of capital depreciation $\left(\mathrm{X}_{3}\right)$ was positive and significant at $1 \%$ level of probability, which implies that increase in capital depreciation will increase cassava yield. A unit increase in capital use will increase output by $0.0545 \mathrm{~kg}$.

The coefficient of labour $\left(\mathrm{X}_{4}\right)$ was positive and significant at $1 \%$ level of probability, this implies that increase in labour will increase cassava yield in the study area. A unit increase in labour use will increase output by $0.6907 \mathrm{~kg}$. This is because there will be enough labour to cultivate the land in a proper agronomic pattern.

Table 2. Production Function of male cassava farmers in Anambra State FADAMA III (AF).

\begin{tabular}{|c|c|c|c|c|}
\hline Variables & Linear & Semi-log & Exponential & Double log \\
\hline Constant & $9.54696(0.0949)$ & $7.5767(224.78)$ & $19845.31(-17.518)$ & $4.1293(50.7219)$ \\
\hline Stem $(\mathrm{x} 1)$ & $2.64876(1.7074)$ & $0.0006(1.1167)$ & $456.525(1.0701)$ & $0.07288(2.3771)^{*}$ \\
\hline Capital input (x3) & $103.5857(3.9225)^{* *}$ & $0.0161(1.8163)$ & $458.019(2.4768)^{*}$ & $0.0545(4.1024)^{* *}$ \\
\hline Labour (x4) & $56.90873(18.016)^{* *}$ & $0.0099(9.3648)^{* *}$ & $3603.37(6.5044)^{* *}$ & $0.6907(17.349)^{* *}$ \\
\hline Farm size (x5) & $7.00863(0.1788)$ & $0.0218(1.6604)$ & $529.0093(-2.3003) *$ & $0.0047(0.2841)$ \\
\hline Adjusted R2 & 0.9835 & 0.9438 & 0.9477 & 0.9918 \\
\hline F-stat & $844.22 * *$ & $239.50 * *$ & $258.066^{* *}$ & $1725.4 * *$ \\
\hline Sample size & 72 & 72 & 72 & 72 \\
\hline
\end{tabular}

Source: Field survey data, (2017). The figure in parenthesis is the t-ratios, ${ }^{*}$ significant at $5 \%$ and $* *$ significant at $1 \%$ level of probability.

\subsection{Determination of Female Cassava Farmer's Production Function}

The information on female farmers production function is presented in Table 3 .

The Double $\log$ function with the highest $\mathrm{R}^{2}$ and in conformity with the a priori expectation was chosen as the lead equation or line of best fit.

Thus, the equation for the female farmer's production function was stated as:

$$
\mathrm{LnY}=6.3291+0.56364 \operatorname{LnX}_{1}+0.02257 \operatorname{LnX}_{2}+0.01088 \operatorname{LnX}_{3}+0.4108 \operatorname{LnX}_{4}+0.00420 \operatorname{LnX}_{5}+0.0031
$$

The coefficients of Multiple Determinant $\left(\mathrm{R}^{2}\right)$ was 0.9969 which implies that $99.69 \%$ variation in cassava yield were explained by the joint action of the independent variables, while the remaining $0.31 \%$ was as a result of error beyond the control of the cassava farmers. The F-statistics value of $4303.74 * *$ significant at $1 \%$ level of probability is an indication that the model was normally distributed.

The coefficient of fertilizer $\left(\mathrm{X}_{2}\right)$, Capital depreciation $\left(\mathrm{X}_{3}\right)$, and farm size $\left(\mathrm{X}_{5}\right)$ were not significant at either $5 \%$ or $1 \%$ level of probability.

The coefficients of cassava cuttings $\left(\mathrm{X}_{1}\right)$ was positive and significant at $1 \%$ levels of probability, which implies that increase in Cassava cuttings used will increase cassava output in the study area. A unit increase in cassava cutting would increase the output of cassava by $0.56364 \mathrm{~kg}$ of the female cassava farmers.

The coefficient of labour $\left(\mathrm{X}_{4}\right)$ was positive and significant at $1 \%$ level of probability which implies that increase in labour will increase the output of female cassava farmers in the study area. A unit increase in the number of labour employed will increase cassava output by $0.4108 \mathrm{~kg}$. Therefore, increasing the labour employment by $1 \%$ will increase output by $41.08 \%$ in the area. 
Table 3. Production Function of Female Cassava Farmer in Anambra State FADAMA III (AF).

\begin{tabular}{|c|c|c|c|c|}
\hline Variable & Linear & Semi-log & Exponential & Double log \\
\hline Constant & $-542.761(1.329)$ & $9.5102(512.63)$ & $123875.60(27.0499)$ & $6.3291(118.18)$ \\
\hline Stem (x1) & $253.711(15.529)^{* *}$ & $0.00480(6.472)^{* *}$ & $28214.15(8.020)^{* *}$ & $0.56364(13.701)^{* *}$ \\
\hline Fertilizer (x2) & $4.3785(1.603)$ & $-4.07795(0.329)$ & $2323.39(1.570)$ & $0.02257(1.3038)$ \\
\hline Capital input (x3) & $57.6832(0.727)$ & $0.00165(0.457)$ & $1182.092(1.495)$ & $0.01088(1.177)$ \\
\hline Labour (x4) & $334.897(12.562)^{* *}$ & $0.0128(10.56)^{* *}$ & $6390.713(1.805)$ & $0.4108(9.920)^{* *}$ \\
\hline Farm size (x5) & $90.2895(0.811)$ & $0.00374(0.739)$ & $711.7116(1.364)$ & $0.00420(0.689)$ \\
\hline $\mathrm{R} 2$ & 0.9956 & 0.9866 & 0.98479 & 0.9969 \\
\hline Adjusted R2 & 0.9953 & 0.9856 & 0.98364 & 0.9967 \\
\hline F-stat & $2981.211 * *$ & $973.8998 * *$ & $854.96 * *$ & $4303.74 * *$ \\
\hline Sample size & 72 & 72 & 72 & 72 \\
\hline
\end{tabular}

Source: Field survey data, (2017). The figure in parenthesis is the t-ratios, $*$ significant at $5 \%$ and $* *$ significant at $1 \%$ level of probability.

\subsection{Allocative Efficiency of Male Cassava Farmers in the Programme}

The Allocative Efficiency of male cassava farmers in the programme is presented in the Table 4 . The decision rule is that if $r=1$, it implies that resources are efficiently utilized where; MVP $=$ MFC $=1, \mathrm{r}>1$, implies that resources are under-utilized, $\mathrm{r}<1$, implies that resources are over utilized.

The result shows that male cassava farmers were allocative inefficient since all the productive resources were over utilized in the area.

Table 4. Allocative Efficiency of Male Cassava farmers in the Anambra State FADAMA III (AF) project.

\begin{tabular}{|c|c|c|c|c|c|c|c|}
\hline Variables & Co-efficient & $\overline{\mathbf{Y}}$ & Price (A) & $\bar{X}$ & MFC (\#) & A. $\mathbf{E}$ & Decision rule \\
\hline Stem (bundle) X1 & 0.0729 & 25.47 & 22000 & 109 & 1500 & 0.25 & over- utilized \\
\hline Fertilizer (kg) X2 & 0.177 & 25.47 & 22000 & 400 & 7000 & 0.035 & Over-utilized \\
\hline Dep. Capital X3 & 0.0545 & 25.47 & 22000 & 2.69 & 32000 & 0.35 & Over-utilized \\
\hline Labour (mandays) X4 & 0.6907 & 25.47 & 22000 & 41 & 76455.7 & 0.12 & Over-utilized \\
\hline Farm size $X 5$ & 0.0047 & 25.47 & 22000 & 2.24 & 16000 & 0.073 & Over-utilized \\
\hline
\end{tabular}

Source: Field Survey Data, 2017

\subsection{Allocative Efficiency of Female Cassava Farmers in the Programme}

The Allocative Efficiency of female cassava farmers in the programme is presented in the Table 5. The decision rule is that if $\mathrm{r}=1$ implies that resources are efficiently utilized where; MVP $=$ MFC $=1, \mathrm{r}>1$ implies that resources are under-utilized; $r<1$ implies that resources are over utilized.

The result shows that female cassava farmers were allocative inefficient since resources like stem cutting was under-utilized while the remaining resources like fertilizer, capital input, labour and farmer size were over-utilized.

Table 5. Allocative Efficiency of Female Cassava Farmers in the Anambra State FADAMA III (AF) Project.

\begin{tabular}{llllllll}
\hline Variables & Co-efficient & $\overline{\mathbf{Y}}$ & Price (\$) & $\overline{\boldsymbol{X}}$ & MFC (\$) & A. E & Decision rule \\
\hline Stem (bundle) X1 & 0.5636 & 22.02 & 22000 & 79 & 1500 & 2.30 \\
Fertilizer (kg) X2 & 0.0226 & 22.02 & 22000 & 375 & 7000 & 0.004 \\
Dep. Capital X3 & 0.0109 & 22.02 & 22000 & 2.34 & 32000 & 0.071 \\
Labour (mandays) X4 & 0.4108 & 22.02 & 22000 & 33.5 & 61167 & 0.097 \\
Farm size X5 & 0.0042 & 22.02 & 22000 & 1.89 & 16000 & 0.067 \\
\hline
\end{tabular}

Source: Field Survey Data, 2017.

\subsection{Factors Militating Against the Resource Use Efficiency of Male and Female Cassava Farmer in FADAMA III (AF) Project}

Results in Tables 6 and 7 revealed the constraints militating against the resource use efficiency of men and women farmers participating in FADAMA III (AF) project in the study area respectively. Using factor analysis, the eighteen (18) constraints identified were loaded under 5 problems according to their order of severity as indicated by the respondents. "Input Insufficiency" with the highest eigenvalues (6.81) and variance $(37.81 \%)$ ranked $1^{\text {st }}$ for male, followed by "less motivation" with eigenvalues (2.57) and variance (14.27\%). However, "Information gap" with eigenvalues (2.50) and variance (13.87\%), "Hectic documentation process" with eigenvalues (1.80) and variance $(10.01 \%)$ and "Lack of ready market to sell the excess output" with eigenvalues (1.74) and variance (9.64\%), ranked as $3^{\text {rd }}, 4^{\text {th }}$ and $5^{\text {th }}$ respectively by male respondents. While in female category, "Input Insufficiency" with the highest eigenvalues (6.72) and variance $(37.35 \%)$ also ranked $1^{\text {st }}$ for female, followed by "Lack of ready market to sell the excess output" with eigenvalues (2.45) and variance (13.65\%). However, "Information gap" with eigenvalues (2.44) and variance (13.55\%), "Less motivation" with eigenvalues (2.32) and variance (12.90\%) and "Hectic documentation" with eigenvalues $(1.80)$ and variance $(10.02 \%)$, ranked as $3^{\text {rd }}$, $4^{\text {th }}$ and $5^{\text {th }}$ respectively for female respondents. 
Table 6. Factor Militating against Resource Use Efficiency of male farmers in FADAMA III (AF) Project.

\begin{tabular}{|c|c|c|c|c|c|}
\hline Constraints male $(n=72)$ & $\begin{array}{l}\text { input } \\
\text { Insufficiency }\end{array}$ & $\begin{array}{l}\text { Less } \\
\text { motivation }\end{array}$ & Information gap & $\begin{array}{l}\text { Hectic } \\
\text { documentation }\end{array}$ & $\begin{array}{l}\text { Lack of } \\
\text { market }\end{array}$ \\
\hline Land tenure system & 0.85 & & & & \\
\hline Inadequate funding & 0.78 & & & & \\
\hline Untimely disbursement of inputs & 0.79 & & & & \\
\hline Untimely counterpart funding of states and LGs & 0.88 & & & & \\
\hline Poor attitude of extension staff towards farmers & & 0.90 & & & \\
\hline low pricing of farm produce from off-takers & 0.72 & 0.53 & & & \\
\hline Ineffective advisory services & & & 0.95 & & \\
\hline High cost of production & 0.82 & & & & \\
\hline Tasking and time consuming of documentation process & & & & 0.71 & \\
\hline Conflict between service providers and client groups & & & & 0.78 & \\
\hline Lack of ready market to sell the excess output & & & & & 0.87 \\
\hline Insufficient credits & 0.86 & & & & \\
\hline FUGs/FCAs in Fadama III are politicized & & & 0.46 & & 0.50 \\
\hline literacy level is a hindrance & 0.88 & & & & \\
\hline lack incentive discourage participation & & 0.90 & & & \\
\hline inability to pay beneficiary contribution & 0.71 & 0.54 & & & \\
\hline lack of crop and livestock specialist & & & 0.95 & & \\
\hline poor quality of inputs from input dealers & 0.82 & & & & \\
\hline Eigen values & 6.81 & 2.57 & 2.50 & 1.80 & 1.74 \\
\hline percentage of Variance & 37.81 & 14.27 & 13.87 & 10.01 & 9.64 \\
\hline
\end{tabular}

Source: Field survey (2017).

Table 7. Factor militating against the resource use efficiency of female farmers in FADAMA III (AF) Project.

\begin{tabular}{|c|c|c|c|c|c|}
\hline Constraints female $(n=72)$ & $\begin{array}{l}\text { input } \\
\text { Insufficiency }\end{array}$ & $\begin{array}{l}\text { Lack of } \\
\text { market }\end{array}$ & Information gap & $\begin{array}{l}\text { Less } \\
\text { motivation }\end{array}$ & $\begin{array}{l}\text { Hectic } \\
\text { documentation }\end{array}$ \\
\hline Land tenure system & 0.85 & & & & \\
\hline Inadequate funding & 0.70 & & 0.48 & & \\
\hline Untimely disbursement of inputs & 0.77 & & & & \\
\hline Untimely counterpart funding of states and LGs & 0.91 & & & & \\
\hline Poor attitude of extension staff towards farmers & & & & 0.95 & \\
\hline low pricing of farm produce from off-takers & 0.75 & & & & \\
\hline Ineffective advisory services & & & 0.99 & & \\
\hline High cost of production & 0.81 & 0.43 & & & \\
\hline Tasking and time consuming of documentation process & & & & & 0.84 \\
\hline Conflict between service providers and client groups & & & & & 0.87 \\
\hline Lack of ready market to sell the excess output & & 0.87 & & & \\
\hline Insufficient credits & 0.84 & & & & \\
\hline FUGs/FCAs in Fadama III are politicized & & 0.86 & & & \\
\hline literacy level is a hindrance & 0.91 & & & & \\
\hline lack incentive discourage participation & & & & 0.95 & \\
\hline inability to pay beneficiary contribution & 0.72 & & & & \\
\hline lack of crop and livestock specialist & & & 0.98 & & \\
\hline poor quality of inputs from input dealers & 0.80 & 0.44 & & & \\
\hline Eigenvalues & 6.72 & 2.45 & 2.44 & 2.32 & 1.80 \\
\hline percentage of Variance & 37.35 & 13.65 & 13.55 & 12.90 & 10.02 \\
\hline
\end{tabular}

Source: Field Survey Data, (2017).

\subsection{Significant Difference in the Cassava Output Among Male and Female Farmers in FADAMA III (AF) Project}

The result of the significant difference in output of male and female cassava farmers shown in Table 7 revealed that there was no significant difference in the farmers cassava output. Thus, the programme had the same effect in the productivity of both male and female cassava farmers. Therefore, null hypothesis one $\left(\mathrm{H}_{0} 1\right)$ was accepted for the study.

Table 8. T-test showing the Significant Difference in the Cassava Output among Male and Female Farmers in FADAMA III (AF) Project.

\begin{tabular}{lllll}
\hline Item & Mean output (tons $\backslash$ ha) & Stand. Devi & Z-. Cal & Z-tab \\
\hline Male & 25.47 & 32.521 & 1.76 & 1.96 \\
Female & 22.02 & 6.320 & & Accept \\
\hline
\end{tabular}

Source: Field Survey Data, 2017. 


\section{Conclusions}

The information from the study is an eye opener to project implementers, the results on farmer's resource allocative efficiency pointed to the fact that farmers are yet to attain efficiency in the management and use of resource. The significant input (explanatory) variable for the male cassava farmers were stem cutting, fertilizer, capital input and labour, while that of female cassava were stem cutting and labour only. The mean farm land of 2.2 ha for male farmers and 1.8ha for female is an indication that cassava farming is done on a contiguous land for easy mechanization and commercialization. Statistically, there was no significant difference in the mean output of 25.47 tons/ha for male and 22.02 tons/ha for female farmers which led to accepting the null hypothesis one in the study.

\section{Recommendations}

Based on the findings of this study, the following recommendations are made:

(i) Government should enhance their capacity towards eliminating the challenges of input insufficiency and untimely disbursement of farm inputs; adequate fund for the project as well as providing quality extension service delivery for the farmers. This will enhance the participation of more farmers.

(ii) Farmers should be trained and given re-orientation on the need to sustain and maintain their continuous active participation in the policies and development programmes of the government, so they can be empowered economically as such alleviate their poverty level.

(iii) Agricultural policy measures should be taken towards provision of ready market with stable prices for cassava produce through creation of marketing boards by the government.

(iv) Labour was found to be the variable that accounted for the highest cost of production and it was over-utilized. Attempts at reducing labour cost will lead to greater Net Farm Income and subsequently, the overall profitability of the enterprise.

(v) Relevant infrastructures such as good access roads from farm gates to markets, electricity and good water supply should be made available by either the government or private sectors.

(vi) Farmers should be discouraged from using unimproved stem cuttings, unfertile lands, unskilled labour and primitive capital inputs by availing them of literal credit facilities.

\section{References}

[1] Amos A. P (2013). Allocative Efficiency of Resource Use by Cassava Farmers in Wamba Local Government Area, NasarawaState, Nigeria; Int. J. Econ. Develop. Res. and Investment. 4 (3), pp: 1-12.

[2] Anyanwu S. O and Iyaba, A. G. (2009). Resource productivity and Efficiency among cassava farmers in River State, Nigeria journal of Agriculture, forestry and social science (JOAFSS). 7 (1), pp: 1-11.

[3] Bassey, N. E., Akpaeti, A. J. and Umoh, I. U. (2014). Determinants of Cassava Output among Small scale Farmers in Nigeria: A Survey of Akwa Ibom State Farmers. Asian Journal of Agricultural Extension, Economics and Sociology, 3 (4); 319-330.

[4] Central Bank of Nigeria (CBN) (2003). Central Bank of Nigeria, Annual Report and statement of account Lagos, Nigeria.

[5] FAOSTAT (Food and Agricultural Organization Statistics) (2012). Searchable online database from Food and Agriculture Division of the United Nations. Rome, Italy Retrieved 22 November 2017 from http://faostat.fao.org/site/567/DesktopDefault.aspx?PageID=5 $67 \#$ anc

[6] FGN (undated). Nigeria; Review of on -Going Agricultural Development Efforts.

[7] FMARD (2012). Federal Ministry of Agriculture and Rural Development Score card FMARD mid-term Report January 1, 2013-Decmber 31, 2017.

[8] Girei A. A., Dire B., Yuguda R. M. andSalihu M. (2014). Analysis of productivity and technical efficiency of cassava production in Ardo-Kola and Gassol Local Government Areas of Taraba State, Nigeria; Agric. For and Fisheries. 3 (1), pp: 1-5. DOI: $10.11648 /$ j.aff.20140301.11.

[9] N. B. S (Nigeria Bureau of Statistics) (2016). Searchable online database from National Bureau of Statistics, Ibadan. Retrieved $2^{\text {nd }}$ November 2017 from www.nigerianstat.gov.ng.

[10] Ndukwu P. C., Nwaru J. C. and Okoye B. C. (2010). Gender and Relative Economic Efficiency in Sweet Potatoe Farmers of Imo State, Nigeria. A stochastic Cost Frontier Approach. The Nigerian Agricultural Journal. 41 (1), pp: 65-70.

[11] Nwaiwu, I., Odii, M., Ohajianya, D., Eze, C., Oguoma, N., Ibekwe, C. H., Adanna, K. F., Amaechi, C., and Oguh, J. (2010). Comparative Analysis of the Productivity of Sustainable Cassava Farming under external and internal input use in Imo State Nigeria. New York Science Journal, 3 (10); $18-25$.

[12] Nwaike, M. C., and Ugwumba, C. O. A. (2016). Economic analysis and determinant of profit from seed yam Dioscorea spp. (Dioscoreales: Dioscoreacea) production in South Eastern Nigeria. International journal of Agricultural policy Research (IJAPR). 4 (7), 111-116.

[13] Obasi, P. C., Henri-Ukoha, A., Ukewuike, S. I., and Chidiebere-Mark, N. M. (2013). Factors Affecting Agricultural Productivity among Arable Crop Farmers in Imo State, Nigeria. American Journal of Experimental Agriculture, 3 (2); 443-454.

[14] Odoemenem, I. U. and Otanwa, L. B. (2011). Economic Analysis of Cassava Production in Benue State, Nigeria. Current Research Journal of Social Sciences, 3 (5); 406-411, 2011.

[15] Ogundari K. and Brummer B. (2010). Estimating Technical Efficiency, Input substitution and complementary effects using Output Distance Function: A study of Cassava production in Nigeria. Contributed paper presented at the joint $3^{\text {rd }}$ African Association of Agricultural Economics (AAAE) and $48^{\text {th }}$ Agricultural Economist Association of South Africa (AEASA) Conference, Cape Town, South Africa. September 19-23, 2010. 28pp. 
[16] Ohen, S. B., Ene D. B. and Umeze G. E. (2014). Resource Use Efficiency of Cassava farmers in Akwalbom State, Nigeria; $J$. Bio. Agric. and Healthcare. 4 (2), 126-131pp.

[17] Oladeebo, J. O. and Oyetunde, O. T. (2013). Relationship Between Plot Size andTechnical Efficiency of Cassava farms in Oyo State of Nigeria; A Stochastic Frontier Analysis, Int. J. Current Res. 5 (17); 2782-2786.

[18] Onubuogu, G. C., Chidebelu S. A. and Eboh E. C. (2013). Enterprise Type, Size and Allocative Efficiency of Broiler Production in Imo State, Nigeria. Int. J. Appl. Res. Technol. 2 (6), pp: 10-19.

[19] Onumadu, F. N. and Nwobiala, C. U. (2012). Assessment of youth participation in yam Minisett Technology in Ivo local Government Area of Ebonyi State, Nigeria. Journal of Economics and Sustainable Development. Vol. 3 (3); 45-50.

[20] Osundu, C. K., Ezeh C. I., Emerole C. O and Anyi C. O (2014). Comparative analysis of technical efficiency of small holder Fadama II and Fadama cassava farmer in Imo State. Nigeria Journal of Rural Extension and Development. 8 (1); 26-37.

[21] Simonyan, J. B., Olukosi J. O., Omolehin R. A. and Atala T. K. A. (2012). Productivity and Technical Efficiency among Beneficiary Farmers of Second National FADAMA Project in Kaduna State, Nigeria. American J. of Experimental Agric. 2 (1), pp: 102-110. 